\title{
PEMBERDAYAAN MASYARAKAT MELALUI OPTIMALISASI PEMANFAATAN JELATANG PADA KELOMPOK TANI SERDANG
}

https://doi.org/10.33024/jkpm.v4i6.5222

\author{
Siti Maimunah ${ }^{1}$, Amila $^{2 *}$, Zuhairiah Nasution ${ }^{3}$ \\ 1,2,3 Universitas Sari Mutiara Indonesia
}

Email Korespondensi: mila_difa@yahoo.co.id

\begin{abstract}
ABSTRAK
Tanaman jelatang banyak ditemukan di Kabupaten Deli Serdang, tapi seringkali hanya dibiarkan kering, layu, mati, dibakar, dibuang karena umumnya hanya dianggap sebagai gulma. Padahal nilai dari tanaman jelatang sangat besar jika dikembangkan karena kaya akan manfaat. Tujuan kegiatan PKM untuk memberdayakan, menguatkan partisipasi masyarakat dalam swamedikasi, optimalisasi potensi tanaman jelatang, penyuluhan kesehatan dengan memberikan informasi mengenai khasiat dan kegunaan tanaman jelatang, membuat krim anti-aging dari ekstrak daun jelatang. Diawal kegiatan, peserta mengisi kuesioner untuk mengukur pemahaman mengenai jelatang. Setelah dilaksanakan penyuluhan, peserta kembali diminta mengisi kuesioner untuk melihat peningkatan pemahamannya. Diakhir kegiatan dilakukan demonstrasi pembuatan krim anti aging dari jelatang. Setelah penyuluhan, pemahaman peserta terkait tanaman jelatang mengalami peningkatan sebanyak $50 \%$ pada Kelompok Tani Sekar Sari dan sebanyak 29,41\% pada Kelompok Tani Dame. Peningkatan pengetahuan dan pemahaman peserta tentang potensi jelatang dapat membantu masyarakat memaanfatkan jelatang secara optimal.
\end{abstract}

Kata Kunci : Tanaman jelatang, krim, anti aging, daun gatal

\section{ABSTRACT}

Nettle plants are commonly found in Deli Serdang Regency, but are often only left to dry, wilt, die, be burned, thrown away because they are generally only considered as weeds. Whereas the value of the nettle plant is very large if it is developed because it is rich in benefits. The purpose of activities is to strengthen community, provide health education about the efficacy and usefulness of nettle plants, formulation of anti-aging cream preparations from nettle leaf extract. At the beginning of the activity, participants were asked to fill out a questionnaire. At the end of the activity, there was a demonstration of making anti-aging cream from nettle. After the counseling, participants' understanding of nettle plants increased by $50 \%$ in the Sekar Sari farmer group and by $29.41 \%$ in the Dame farmer group. Increased knowledge and 
understanding of participants about the potential of nettles can help the community to use nettle optimally.

Keywords : Nettle plants, cream, anti aging, itchy leaves

\section{PENDAHULUAN}

Deli Serdang merupakan salah satu Kabupaten yang terdapat di Sumatera Utara, dimana di Kabupaten tersebut terdapat Desa Wonosari merupakan salah satu desa yang berada di kecamatan Tanjung Morawa dan Desa Kolam, Kecamatan Percut Sei Tuan, di kedua desa ini terkenal dengan masyarakatnya menjadi petani. Banyak tersebar daun jelatang yang tumbuh di lahan mereka. KT di Kabupaten Deli Serdang merupakan PKM dengan kategori masyarakat yang produktif secara ekonomi atau pengusaha mikro. Akan tetapi tanaman jelatang hanya dibasmi karena merugikan dan jika tersentuh maka area kulit.

Produk unggulannya adalah sayur, lahan mitra juga terdapat tanaman jelatang, namun keberadaan tanaman jelatang dilahan mereka dianggap merugikan karena jika bagian kulit yang tersentuhnya akan berbintik-bintik merah, gatal, dan panas, sehingga tanaman jelatang hanya dibasmi tanpa diperlakukan khusus karena ketidakpahaman mitra akan manfaat potensial tanaman jelatang padahal jika dikembangkan, bisa menjadi produk inovasi baru yang tepat guna sehingga bisa menjadi solusi untuk mengatasi kerugian bertanam sayur karena tanaman jelatang tidak membutuhkan biaya banyak dalam proses perawatannya sampai panenmengubah mindset masyarakat tentang tanaman jelatang yang dianggap beracun dengan membasmi tanaman jelatang padahal memiliki manfaat dibidang kesehatan dan pangan

Daun gatal merupakan tanaman dimana bentuk daun bergerigi dan memiliki bulu-bulu halus di sepanjang daun dan batang (Gambar 1). Tanaman daun gatal dengan spesies yang berbeda di antaranya Laportea aestuan (Okereke \& Elekwa, 2014), L. ovafolia (Nzeugeumet al., 2015), L. interrupta (Njina et al., 2006; Tchinda et al., 2017), L. canadiensis (Reauma, 2010; Tuberville et al., 2007), juga dimanfaatkan di negara-negara lain seperti di Nigeria, Kamerun, Filipina (Oloyede \& Oyelola, 2013; Oloyede, 2016), Bangladesh, Sri Langka, India (Khan et al., 2007), dan beberapa negara di Eropa. Ekstrak daunnya memiliki aktivitas antioksidan yang kuat (Saad \& Omar, 2011), sehingga dapat digunakan lebih lanjut untuk membantu perawatan anti-aging kulit (Ferguson, 2011).

Sediaan dihasilkan dari hasil penelitian yang sudah dilakukan produk simplisia dan sediaan krim anti-aging .dari ekstrak etanol daun jelatang (Urtica dioica L.) (Maimunah, Nasution, Am

ila, 2020). Tipe A/M yang homogen, dengan $\mathrm{pH} 7$, viskositas $28.000 \mathrm{cps}$, stabil dalam penyimpanan selama 28 hari, dan tidak mengiritasi kulit sukarelawan. Hasil analisis dengan skin analyzer menunjukkan perubahan kondisi kulit menjadi lebih baik yaitu kadar air bertambah, pori dan kerutan berkurang. Sediaan krim dengan konsentras 0,5\% menunjukkan efektivitas anti- aging terbaik.

Daun jelatang mengandung klorofil, protein, karotenoid seperti lutein, $B$ karoten, dan isomernya, mineral di antaranya zat besi, fosfor, magnesium, kalsium, potasium, sodium, vitamin B, C, dan K (Zeipina, et al, 2014), flavonoid seperti isokuersetin dan rutin, tannin, histamine, serotonin, asam format, asam resin, glukokinin (Shilpi et al, 2017), asam linoleat, asam 
ursolik, neoxanthin, violaxanthin, likopen (Shailajan et al, 2014). Polisakarida, vitamin C, karoten serta flavonoid quercetin, rutin, kaempferol, dan beta-sitosterol (Fragoso et Gambar 1. Daun Jelatang (Urtica diocia $\mathrm{L}$ ). Anti- aging atau anti penuaan adalah sediaan yang berfungsi yang menghambat proses kerusakan pada kulit (degeneratif), sehingga mampu menghambat timbulnya tanda-tanda penuaan pada kulit beberapa bahan yang terdapat pada produk anti-aging: Peptida, anti oksidan, vitamin C, vitamin $\mathrm{E}$ (Muliyawan \& Suriana, 2013).

Berdasarkan kondisi mitra, KT "Sekar Sari" Desa Wonosari dan "Dame" Kabupaten Deli Serdang sangat berkeinginan mengembangkan usaha yang dikelola, sehingga perlu dilakukan teknologi tepat guna, pelatihan pembuatan serbuk daun jelatang dan krim anti-aging, penyuluhan kesehatan tentang potensi tanaman herbal dan manfaatnya.

\section{MASALAH}

Alasan kami memilih tempat kegiatan karena kedua kelompok Tani yang terdapat Desa Wonosari di Tanjung Morawa dan Desa Kolam di Percut Sei Tuan Kabupaten Deli Serdang merupakan salah satu kelompok tani produktif secara ekonomi, banyak menanam sayuran. Di sekitar lahan pertanian kedua kelompok tani banyak tersebar daun jelatang, namun hanya dibuang, dibakar karena dianggap tidak berguna.

Tujuan kegiatan PKM untuk memberdayakan, menguatkan partisipasi masyarakat dalam swamedikasi, optimalisasi potensi tanaman obat daun jelatang, penyuluhan kesehatan dengan memberikan informasi mengenai khasiat dan kegunaan tanaman jelatang, membuat sediaan krim anti-aging dari ekstrak daun jelatang.
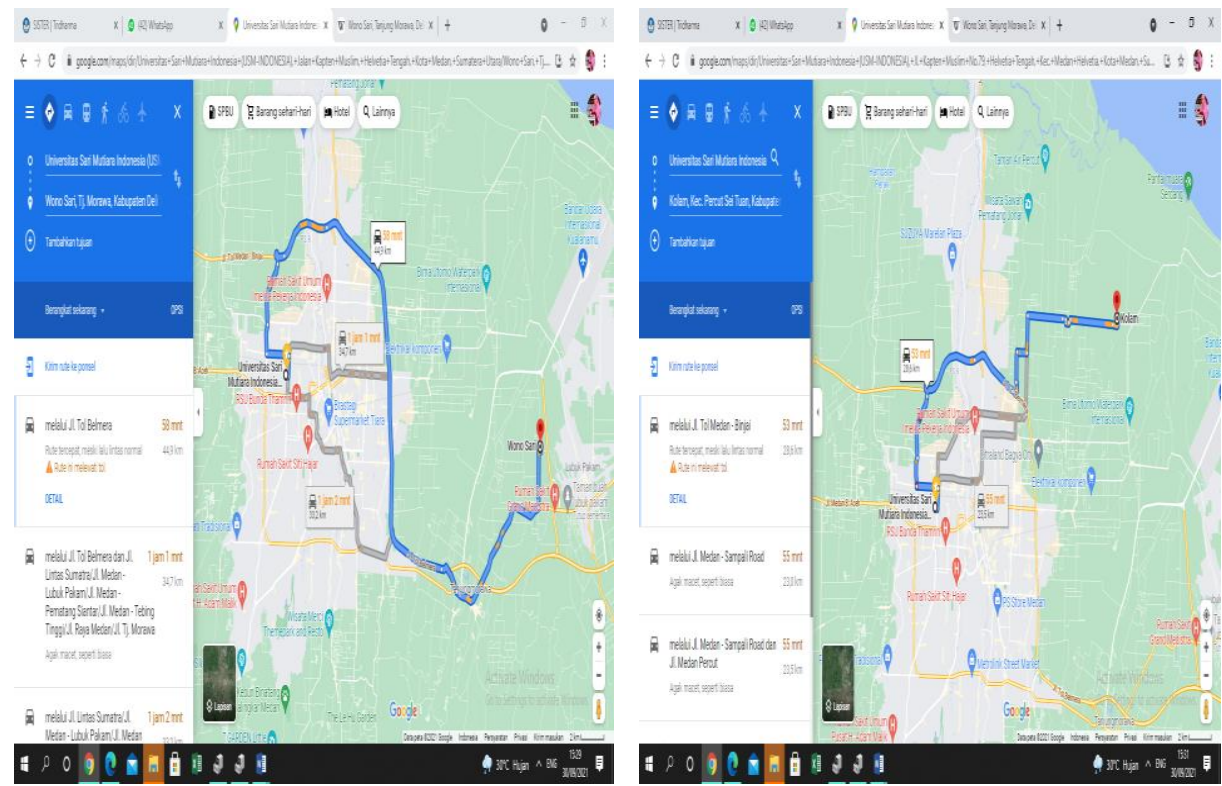

Gambar 2.1

Peta Lokasi Kegiatan Pengabdian Masyarakat (Desa Kolam dan Desa Wonosari Kabupaten Deli Serdang) 


\section{METODE}

a. Tujuan Persiapan

Tahap persiapan dari kegiatan adalah pembuatan pre planning, persiapan pemberian edukasi, pembuatan serbuk daun jelatang, pembuatan Gel Anti Aging dari serbuk Daun Jelatang.

b. Tahap Pelaksanaan

Sasaran utama dalam kegiatan pengabdian kepada masyarakat ini adalah kelompok tani di Kabupaten Kegiatan ini diikuti oleh 29 orang peserta dari kedua Kelompok Tani (KT) yaitu KT Dame sebanyak 17 orang dan KT Sekar Sari sebanyak 12 orang karena adanya Pembatasan Pemberlakuan Kegiatan Masyarakat (PPKM) oleh pemerintah, sehingga jumlah peserta dibatasi. Kegiatan pengabdian masyarakat dilaksanakan di dua tempat, yaitu di Balai Desa Wonosari Kecamatan Tanjung Morawa untuk Kelompok Tani Sekar Sari dan di Balai Desa Kolam Kecamatan Percut Sei Tuan untuk Kelompok Tani Dame

Pelaksanaan kegiatan meliputi :

1. Pendekatan dalam melakukan pengabdian kepada kedua kelompok Tani dilakukan melalui komunikasi

2. Penanaman daun jelatang di lahan pada kelompok Tani Dame dan Sekarsari Kabupaten Deli Serdang.

3. Sebelum diberikan sosialisasi, diawali dengan pembagian kuesioner kepada peserta untuk mengetahui pengetahuan peserta mengenai tanaman jelatang Workshop dan sosialisasi serta pelatihan dilakukan.

4. Kegiatan sosialisasi dan penjelasan penerapan teknologi Farmasi bahan alam dalam meningkatkan nilai jual dari daun jelatang atau daun gatal. Pembuatan ini dibimbing oleh tim pelaksana dari staf Farmasi USM Indonesia dengan melibatkan mahasiswa dan masyarakat setempat.

5. Setelah diberikan sosialisasi dibagikan kuisioner untuk mengetahui peningkatan pengetahuan peserta tentang jelatang.

6. Demonstrasi pembuatan krim anti aging dari daun jelatang. Sediaan dihasilkan dari hasil penelitian yang sudah dilakukan produk simplisia dan sediaan krim anti-aging .dari ekstrak etanol daun jelatang (Urtica dioica L.). Daun jelatang segar dibersihkan dari partikel asing, direndam dalam air, diangin- anginkan, dikeringkan menggunakan lemari pengering. Daun gatal dihaluskan dan dibuat menjadi simplisia. Simplisia diayak menjadi 25-75 $\mu \mathrm{m}$ dan dimasukkan dalam kemasan dan dipacking dengan baik. Setelah simplisia diperoleh kemudian diformulasi dengan bahan-bahan yang lain untuk menghasilkan produk daun gatal. Uji Iritasi telah dilakukan terhadap 6 orang sukarelawan menggunakan krim ekstrak jelatang dengan konsentrasi tertinggi yaitu 0,5\% dengan cara sediaan krim dioleskan di kulit punggung tangan membentuk lingkaran, lalu biarkan selama 24 jam, diamati setiap 4 jam sekali apakah terjadi iritasi kulit atau tidak.

c. Evaluasi

Evaluasi kegiatan dilakukan dengan memberikan kuisoner. Setiap peserta akan dibagikan kuisoner dan diminta mengisi baik biodata, pemahaman atau pengetahuan tentang kegiatan yang dilakukan. Selanjutnya data disimpan dan dianalisis dan tingkat keberhasilan kegiatan dapat diukur. Evaluasi keberlanjutan program dilakukan pemantauan setelah kegiatan telah selesai dan masyarakat melakukan hasil kegiatan pengabdian ini. 


\section{HASIL DAN PEMBAHASAN}

Antusias peserta dalam kegiatan ini sangat tinggi dibuktikan dengan banyaknya pertanyaan dari peserta. Kelompok Tani Sekar Sari dan Dame belum pernah mengenal banyak tanaman jelatang. Peserta yang mengikuti kegiatan ini diklasifikasikan berdasasarkan jenis kelamin, usia, pekerjaan, pendidikan, dan umur. Kedua peserta KT terdiri 25 orang perempuan, 4 orang laki-laki. Rentang usia peserta yang mengikuti pengabdian ini adalah usia 16- 65 tahun.

Pembuatan dilakukan dengan cara mempraktekkan langsung tahap demi tahap, sehingga masyarakat memahami cara melakukannya secara mandiri. Hasil pengukuran tingkat pengetahuan peserta mengenai tanaman jelatang dapat dilihat pada tabel 1 dan 2.

Tabel 1. Tingkat Pengetahuan Peserta Tentang Tanaman Jelatang Sebelum Penyuluhan $(n=29)$

\begin{tabular}{cccc}
\hline Kelompok Tani & Kategori & $\begin{array}{c}\text { Banyak Peserta } \\
\text { (orang) }\end{array}$ & $\%$ \\
\hline \multirow{4}{*}{ Sekar Sari } & Baik & 1 & $8,33 \%$ \\
& Cukup & 1 & $8,33 \%$ \\
& Kurang & 10 & $83,33 \%$ \\
& Jumlah & 12 & $100 \%$ \\
\hline \multirow{4}{*}{ Dame } & Baik & 4 & $23,53 \%$ \\
& Cukup & 5 & $29,41 \%$ \\
& Kurang & 8 & $47,06 \%$ \\
\hline
\end{tabular}

Tabel 21. Tingkat Pengetahuan Peserta Tentang Tanaman Jelatang Setelah Penyuluhan $(n=29)$

\begin{tabular}{cccc}
\hline Kelompok Tani & Kategori & $\begin{array}{c}\text { Banyak Peserta } \\
\text { (orang) }\end{array}$ & \multicolumn{1}{c}{$\%$} \\
\hline \multirow{4}{*}{ Sekar Sari } & Baik & 7 & $58,33 \%$ \\
& Cukup & 3 & $25,0 \%$ \\
& Kurang & 2 & $16,67 \%$ \\
& Jumlah & 12 & $100 \%$ \\
\hline \multirow{3}{*}{ Dame } & Baik & 9 & $52,94 \%$ \\
& Cukup & 5 & $29,41 \%$ \\
& Kurang & 3 & $17,65 \%$ \\
\hline
\end{tabular}
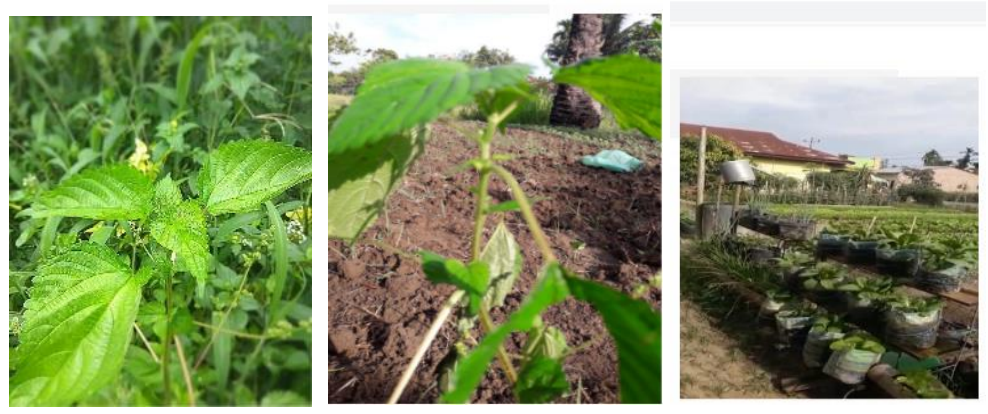

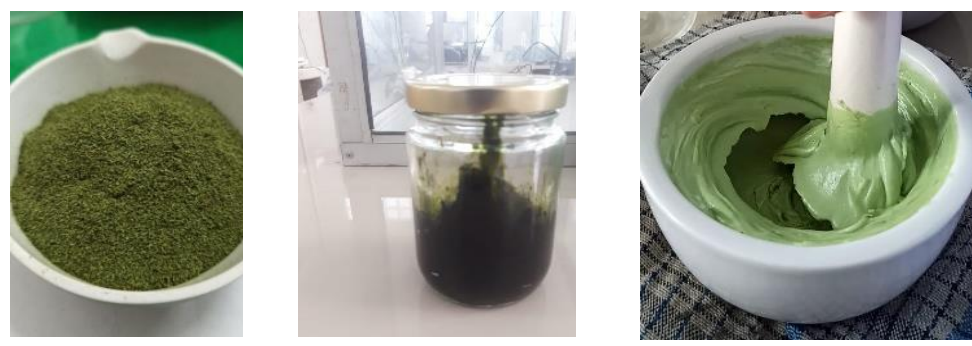

Gambar 1. Penanaman Jelatang dan pembuatan sediaan krim Jelatang
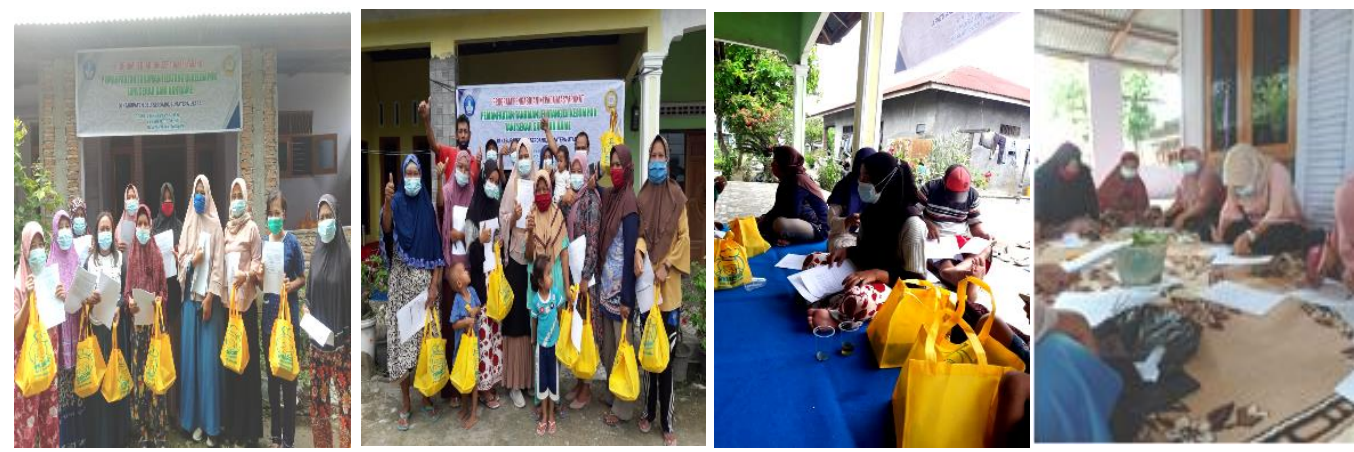

Gambar 2. Sosialisasi Pemanfaatan Jelatang di KT Dame dan Sekarsari

Berdasarkan tabel 1, sebelum dilakukan penyuluhan tentang pemanfaatan tanaman jelatang, mayoritas pengetahuan kelompok tani Sekar Sari belum mengenal tanaman jelatang $(83,33 \%)$ dan pengetahuan kelompok tani Dame sebanyak 47,06\% peserta belum mengenal tanaman jelatang. Berdasarkan tabel 2 , setelah dilakukan penyuluhan mayoritas pengetahuan masyarakat dalam pengenalan jelatan pada kelompok tani Sekar Sari dalam kategori baik $(58,33 \%)$ dan pengetahuan kelompok tani Dame dalam kategori baik $(52,94 \%)$. Terjadi peningkatan pengetahuan kelompok tani Sekar Sari sebanyak 50\% dan kelompok tani Dame sebanyak 29,41\%

Kurangnya pengetahuan masyarakat mengenai tanaman jelatang tentu sangat disayangkan mengingat tanaman jelatang merupakan tanaman yang mudah ditemui di lingkungan sekitar peserta dan memiliki banyak manfaat serta potensi yang dapat dikembangkan. Hasil penelitan Simaremare et al (2019), sebanyak 88,9\% peserta memperoleh manfaat dari kegiatan ini dan 70,4\% berkomitmen akan membantu orang lain dalam menyebarluaskan informasi penting yang mereka dapat pada waktu kegiatan ini.

Daun gatal atau daun jelatang (Urtica dioica L.) merupakan tanaman dimana bentuk daun bergerigi dan memiliki bulu-bulu halus di sepanjang daun dan batang. Daun jelatang mengandung klorofil, protein, karotenoid seperti lutein, $B$ karoten, dan isomernya, mineral diantaranya zat besi, fosfor, magnesium, kalsium, potasium, sodium, vitamin B, C, dan K (Zeipina, Ina \& Liga, 2014), flavonoid seperti isokuersetin dan rutin, tannin, histamine, serotonin, asam format, asam resin, glukokinin (Shilpi, Singh, Parashar \& Gupta, 2017), asam linoleat, asam ursolik, neoxanthin, violaxanthin, likopen (Shailajan, Dipti, Harshada \& Bhavesh, 2014), Polisakarida, vitamin C, karoten serta flavonoid quercetin, rutin, kaempferol, dan beta-sitosterol (Fragoso et al, 2008).

Daun gatal memiliki aktivitas anti bakteri yang baik terhadap bakteri E.coli, S. aureus, dan S.thypi (Simaremare dkk, 2017). Ekstrak etanol daun gatal juga memiliki aktivitas antikoagulan, antiinflamasi, analgesik, antibakteri, sitotoksik 
(Simaremare et al., 2018; Simaremare et al., 2019). Simplisia daun gatal juga sudah berhasil dibuat obat anti nyeri dalam sedian salep dan dalam pengembangan produk (Simaremare dkk, 2014; Holle dkk, 2015a;Holle dkk, 2015b).

Kedua kelompok tani diajarkan cara menanam jelatang di lahan pertanian mereka, membuat serbuk daun jelatang. Kegiatan pengabdian ini mendapat apresiasi dari masyarakat karena desa jarang didatangi sosialisasi seperti pada kegiatan ini. Pada kegiatan ini juga disampaikan krim anti aging daun jelatang. Ekstrak daunnya memiliki aktivitas antioksidan yang kuat (Saad \& Said, 2011) sehingga dapat digunakan lebih lanjut untuk membantu perawatan anti aging kulit (Ferguson, 2011). Hasil penelitian Maimunah, Nasution, Amila (2020) menunjukkan perubahan kondisi kulit menjadi lebih baik yaitu kadar air bertambah, pori dan kerutan berkurang. Sediaan krim dengan konsentrasi 0,5\% menunjukkan efektivitas anti-aging terbaik.

\section{KESIMPULAN}

Kegiatan pengabdian kepada masyarakat dapat terlaksana dengan baik dan berhasil. Kegiatan ini dapat terlaksana dengan lancar dan berhasil atas partisipasi dari tim pelaksana. Umumnya peserta belum pernah mengikuti kegiatan yang sama. Setelah penyuluhan, pemahaman peserta terkait tanaman jelatang mengalami peningkatan sebanyak $50 \%$ pada Kelompok Tani Sekar Sari dan sebanyak 29,41\% pada Kelompok Tani Dame.

Kelompok Tani Sekar Sari dan Dame juga diajarkan pelatihan desain packaging, pembuatan sosial media facebook "Teh jelatang”, instagram : @tehjelatang, website : www.desaunggulandeliserdang.com.

\section{UCAPAN TERIMA KASIH}

Ucapan terima kasih disampaikan kepada Kemendikbud Ristek yang telah mendanai kegiatan ini dalam bentuk Hibah Program Kemitraan Masyarakat tahun 2021. Penulis juga mengucapkan terima kasih sebesar-besarnya kepada Ketua Kelompok Tani Sekar Sari dan Dame Deli Kabupaten Deli Serdang yang telah memberikan dukungan, fasilitas dan sarana prasarana selama melaksanakan pengabdian kepada masyarakat.

\section{DAFTAR PUSTAKA}

Aksu, M.I., \& M. Kaya. (2004). Effect of Usage Urtica dioica L. On Microbiological Properties of Sucuk, A Turkish Dry-Fermented Sausage. Food Control, 15: 591-595.

Ali A, Akhtar N, Chowdhary F.2014. Enhancement of human skin facial revitaliation by Moringa leaf extract cream. Posted Derm Alergue: 31 (2): 71-6.

Ferguson, S. (2011). Eastern European beauty secrets and skin care techniques: A practical manual for skin care professionals. Pennsylvania: RoseDog Books.

Fragoso, L.R., Jorge R.E., Scott, W.B., Dea, H.R., \& Eliseo, T. (2008). Risk and benefits of commonly used herbal medicines in Mexico. Toxicology and Applied Pharmacology. 227: 128-135. 
Heyne K. (1987). Tumbuhan Berguna Indonesia II. Jakarta: Badan Litbang Kehutanan.

Holle, E, et al. (2015a). Evaluasi, Uji Aktivitas, Dan Pengembangan Produk Salep Daun Gatal Papua Varietas Biak. Jurnal Biologi Papua. Prosiding Seminar Nasional Biologi PBI ke -XXIII . Jayapura 8-9 September 2015.

Holle, E. et al. (2015b). Analisis Perbandingan Efektifitas Antinyeri Salep Daun Gatal Dari Simplisia Laportea Aestuans (L)

Khan, A. M. A. B, M. Abdul, A. Al-Bari, S Hasan, M. A. Mosaddik, M. M. Rahman, M. E. Haque. (2007). Antipyretic activity of roots of Laportea crenulata Gaud in rabbit.Research Journal of Medicine and Medical Sciences, 2(2):58-61.

Maimunah, S., Nasution, Z., \& Amila, A. (2020). Pemanfaatan Ekstrak Daun Urtica Dioica L. Sebagai Anti-Aging Alami Dalam Sediaan Krim. Jurnal Penelitian Saintek, 25(2), 124-134.

Nzeugeum K. W. M., M. O. L. Dongmo, L. L. Lienou, P. B. Telefo. (2015). Effect of Laportea ovalifolia (urticaceae) on monosodium glutamate induced obese rats. African Article of Integrated Health, 5(2):48-53.

Njina S. N., R. S. Tagne, B.P. Telefo, F. N. Zambou, D. M. Yemele, F. T. Mbiapo. (2006). Anti-androgenic, anti-oestrogenic, and antioksidan activities of aqueous extract of Laportea ovalifolia on adult rats. Internasional Journal of Phytomedicine, 8:257-266.

Okereke, S. C., I. Elekwa. (2014). Studies the in vitro antioxidant activity of Laportea aestuans leaf extract. J of Environmental Sci, Toxicology and Food Technology, 8(1):33-41.

Oloyede, G. K., M. S. Oyelola (2013). Chrysen-2-ol-derivate from West Indian wood nettle Laportea aestuans (L.) Chew inhibits oxidation and microbial growth in vitro. EXCLI Journal, 12:894-906.

Oloyede, G. K. (2016). Toxicity, antimicrobial and antioxidant activities of methyl salicylate dominated essential oils of Laportea aestuans (Gaud.). Arabian Journal of Chemistry, 9(1):840-5.

Muliyawan, D., \& Suriana, N. (2013). A-Z Tentang Kosmetik. Jakarta: PT. Elex Media Komputindo. Halaman 16-17, 139, 289.

Saad, Bashar \& Said, Omar. (2011). Greco-Arab and Islamic Herbal Medicine: Traditional System, Ethics, Safety, Efficacy and Regulatory Issues. 10.1002/9780470944363.

Shailajan, S., Dipti, S., Harshada, H., dan Bhavesh, T. (2014). Estimation of Ursolic Acid From Urtica dioica L. Using Validated HPTLC Method. JAPS, : 40517.

Shilpi, J., Singh, K., Parashar, A., Gupta, D. (2017). A Drug: Urtica dioica. Journal of Drug Discovery and Therapeutics, 5(2): 17-22.

Simaremare, E. S., Pratiwi, R. D., Rusnaeni, R., Gunawan, E., \& Dirgantara, S. (2019). Pemanfaatan Tanaman Daun Gatal (Laportea Decumana) Sebagai Obat Anti Capek. JPPM (Jurnal Pengabdian dan Pemberdayaan Masyarakat), 3(1), 97-103.

Simaremare, E. S. et al. (2017). Aktivitas Antibakteri Ekstrak Etanol Daun Gatal (Laportea aestuans (L) Chew) Jurnal Biologi Papua, 9(1).

Simaremare, E.S. et al. (2018). Toxicity, Antioxidant, Analgesic and Anti inflamantory of Ethanol Extract of Laportea aestuans (Linn.) Chew. J Chem Pharm Res., 10 (5):16-23.

Zeipina, S., Ina, A., dan Liga, L. (2014). Stinging Nettle-The Source of Biologically Active Compounds As Sustainable Daily Diet Supplement. Research For Rural Development. 